\title{
Macro-logistics trends: Indications for a more sustainable economy
}

\author{
Authors: \\ Jan H. Havenga ${ }^{1}$ \\ Zane P. Simpson \\ Anneke de Bod ${ }^{1}$ \\ Affiliations: \\ ${ }^{1}$ Department of Logistics, \\ University of Stellenbosch, \\ South Africa \\ Correspondence to: \\ Jan Havenga \\ Email: \\ janh@sun.ac.za

\section{Postal address:} \\ Department of Logistics, \\ Private Bag X1, Stellenbosch, \\ Matieland, 7602, \\ South Africa \\ Dates: \\ Received: 27 June 2013 \\ Accepted: 23 Aug. 2013 \\ Published: 24 Oct. 2013 \\ How to cite this article: \\ Havenga, J.H., Simpson, Z.P. \\ \& De Bod, A., 2013, 'Macro- \\ logistics trends: Indications \\ for a more sustainable \\ economy', Journal of \\ Transport and Supply Chain \\ Management 7(1), Art. \\ \#108, 7 pages. http://dx.doi. \\ org/10.4102/jtscm.v7i1.108

\section{Copyright:} \\ (C) 2013. The Authors. \\ Licensee: AOSIS \\ OpenJournals. This work \\ is licensed under the \\ Creative Commons \\ Attribution License.
}

Read online:

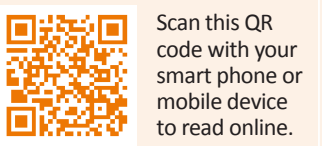

The North American and South African logistics cost calculation-time series are the two longest-running statistical series available worldwide. These calculations indicate that transportation's contribution to logistics costs is rising, as the key cost driver (oil price) is increasing exponentially. This is exacerbated by volatile oil prices and the inclusion of externality charges to reduce the logistics environmental footprint. Therefore, it is necessary to consider a new paradigm where material logistics requirements are reduced through localisation and consumption reduction. This, in turn, implies the consideration of new indicators for the future measurement of logistics costs. Because this article asks questions about the suitability of GDP as the primary (and often only) measurement of economic output, new measurements are required. If this position changes, the comparison of logistics costs with GDP alone will become questionable.

\section{Introduction}

Due to the strained global economic environment it is necessary to analyse the underlying trends in national logistics costs and compare them to the national output. Once this has been done, key areas for improvement can be identified.

As recently as 2009, Klaus reported on the difficulties involved in aggregating national level measurement. Rantasila and Ojala (2012) analysed national logistics cost surveys in a global survey and confirmed that logistics costs are a major driver for competitiveness on a national level; this is not included in any global ranking scales. They distinguished between surveybased, statistical-based and case study-based measurements, then analysed 14 survey-based and 11 statistical-based measurements around the world. Their analysis indicated a rise in attempts to perform the logistics costs measurements on a country or national level. However, only five surveys exist that have been completed consistently every year over the last five-year period. Of these five, only two (that of the USA and South Africa) have provided a time-series of national logistics costs per cost component.

This article underscores the merits of national logistics cost measurement in order to encourage this growing body of knowledge. It also analyses the long-term logistics cost trends of the USA and South African results. Resulting perspectives are informed by a literature analysis of current key-global trends. It is hoped that this may influence the way in which logisticians think about logistics costs and the way in which researchers report on them.

\section{The merit of national logistics cost measurement}

Logistics is an integral component of macroeconomics as it enables specialisation (and thereby economic growth) through the efficient and effective distribution of resources and outputs (Pienaar 2009). The comparative efficiency of a country's logistics chain is of vital importance in enhancing the competitiveness of its industry and commerce (United Nations 2002). Lakshmanan and Anderson (2002) have shown that improved productivity in the freight transport sector enhances the productivity of the overall economy. Rasamit (2003) found correlations between total factor productivity and total logistics costs. In a technical study to determine the quantitative role of transport in international business cycles, Ravn and Mazzenga (2004) estimated that a reduction in transport costs from $20.0 \%$ to $15.0 \%$ of Gross Domestic Product (GDP) is equivalent to a permanent increase in domestic consumption of just above $1.5 \%$. In a detailed historical analysis spanning 106 years, Fedderke, Perkins and Luiz (2006) demonstrated that the impact of infrastructure investment on economic growth in South Africa is both strong and statistically significant.

Strategic attention to logistics as a source of competitive advantage is a relatively new phenomenon; it follows on from product quality during the 1980s and superior customer service during the 1990s (Gourdin 2001). The element of macro-logistics that receives most 
attention is logistics infrastructure investment, which is viewed as a direct economic injection that strengthens the capital production factor (Lakshmanan \& Anderson 2002). Lakshmanan and Anderson (2002) however suggested a more robust understanding of the effect of different transport modes on network design in order to benefit the economy as a whole. In South Africa, the infrastructural component is understood in general, but there is a lack of understanding of the concomitant network and modal view. According to Fourie (2008), the policy and research emphasis in South Africa is still on infrastructural quantity as opposed to quality. Bogetić and Fedderke (2006) benchmarked South Africa's transport performance on basic road and rail indicators against upper-middle-income countries based on a World Bank database. The authors concluded that South Africa performs worse than the benchmarked upper-middleincome countries, and recommended a deeper analysis of the transport sector in order to develop a more 'nuanced picture' between the different modes.

Infrastructure configuration is therefore an important dimension in the applicability and use of national logistics cost-measurement systems. Rantasila and Ojala (2012), and Kwon and Beom (2012), extended the infrastructure improvement view to include the application of these measurement systems in policy improvement, not only in the transport sector, but also across sectors. Solakivi et al. (2012) extended the usefulness of countrywide surveys by introducing a strong development focus in the latest Finnish State of Logistics Survey (Solakivi et al. 2012). They argued for social remedies, such as ensuring adequate supplies of skilled and expert labour through first rate training and research. Achieving these objectives can be supported by logistics cost research.

\section{Research approach}

The approach for calculating South Africa's freight logistics costs is quantitative and described by Havenga (2010). The logistics cost model employs both a bottom-up and top-down approach to the computation of logistics costs by aggregating detailed commodity-specific data; this is related to the tons produced and imported (that is total supply) of a specific commodity and the costs of performing logistical functions with respect to that commodity. The logistics-cost elements measured were: transport; storage and port handling costs; management and administration costs; and inventory carrying costs. The total transport cost was measured by calculating the cost of transport by road (both distribution and line haul), rail, air, coastal shipping and pipeline.

Logistics-cost data for the USA was obtained from Wilson (2011).

The discussion regarding the new logistics paradigm is based on a literature survey. The synthesis of the survey results and desktop analysis culminated in recommendations for key macro-logistics interventions and future logistics-cost measurements.

\section{Long-term trends in logistics costs}

In 2011, South Africa's logistics costs when compared to GDP rose by $0.7 \%$ to $12.6 \%$ (Figure 1 ). Although this indicator has shown a declining trend since the inception of South Africa's annual logistics cost survey, the significant increase in transport costs (as predicted in previous surveys and identified as a major risk) of $24.0 \%$ year-on-year is disturbing. At $61.0 \%$ of logistics costs, the contribution of transport costs is at its highest level since survey inception and is significantly higher than the global average of $39.0 \%$ (Rodrigue, Comtois \& Slack 2009).

This trend, when transportation becomes a larger portion of total logistics costs whilst inventory costs decline, as observed in the USA (Figure 2), is also evidenced in South Africa.

South Africa's inventory and transportation costs are driven by the respective underlying exogenous cost drivers, the prime interest rate and price of diesel, which are moving in different directions (Figure 3).

Carrying cost (on a national level presented by the prime interest rate) will rise when economies recover, but it is never at risk in the same way as a natural resource, such as crude oil (Figure 4).

The future transportation risk of emission costs inclusion (Piecyk \& McKinnon 2007; McKinnon 2009) and rising fuel prices (Manrodt \& Holcomb 2011; Engblom et al. 2012) will accelerate this trend and necessitate the introduction of a new paradigm in terms of logistics-cost management and measurement.

\section{The oil price risk to freight-transport costs}

More than $90.0 \%$ of the energy for transportation in the world is supplied by oil (Fantazzini, Hoök \& Angelantoni 2011). Freight transport accounts for $40.0 \%$ of a company's totallogistics costs (McKinnon 2009) and a similar percentage of global-logistics costs (Roberts 2003). The economic sensitivity to oil price fluctuations is especially pronounced in oil-importing developing countries (which are generally more energy-intensive and less energy-efficient). For these countries, in the year following a sustained US $\$ 10$ oil-price increase, the loss of GDP is more than $3.0 \%$ compared to $0.3 \%$ in the USA and $0.4 \%$ in Organisation for Economic Co-operation and Development member (OECD) countries (International Energy Agency [IEA] 2004). Transportation Economics \& Management Systems (TEMS) (2008) estimated that the oil price rise from US\$20 per barrel in 2000 to US\$140 per barrel in 2008 led to a five-fold to eight-fold increase in the fuel price for marine and inland shipping.

Although general consensus is lacking, the key drivers put forward for the oil price peak of US\$147 per barrel in mid2008, were: commodity market speculation; short-term supply or demand imbalances; and the Israel and/or Iran conflict - all of which are still causes for concern (Eghbal 2008; Hopkins 2008; Schlumberger 2009; Brush 2012). 


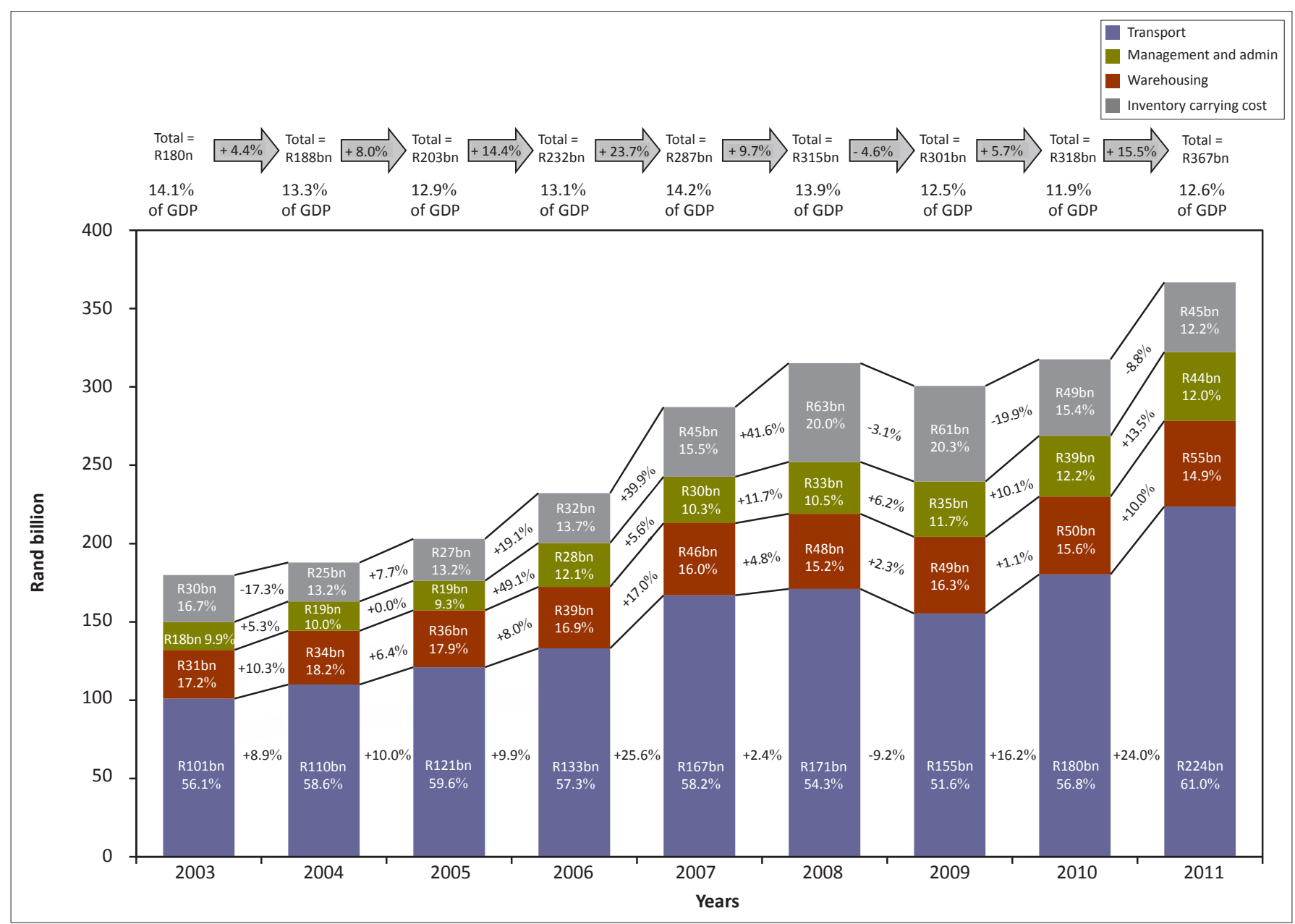

Bn, billion; GDP, Gross Domestic Product

FIGURE 1: South Africa's logistics costs components and Gross Domestic Product comparison.

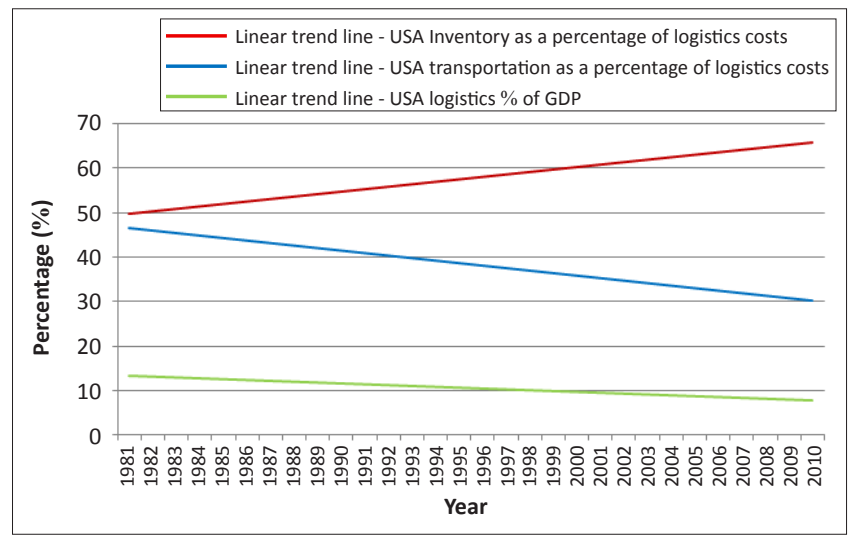

Source: Wilson, R., 2011, '21st Annual State of Logistics Report: The Great Freight Recession', Council of Supply Chain Management Professionals, Washington

FIGURE 2: Linear trends of logistics cost components in the USA.

Subsequently, the USA's near zero interest rate policy and unprecedented increase in money supply by the Federal Reserve Bank, has increased global liquidity, sustained emerging market growth, fuelled commodity demand strength and raised commodity prices (including crude oil) (Fontevecchia 2012; Jegarajah 2013). Whilst the 2012 Spillover Report, published by the International Monetary Fund, found no significant evidence of dollar depreciation being driven by US monetary policy (Chan 2013), quantitative easing was

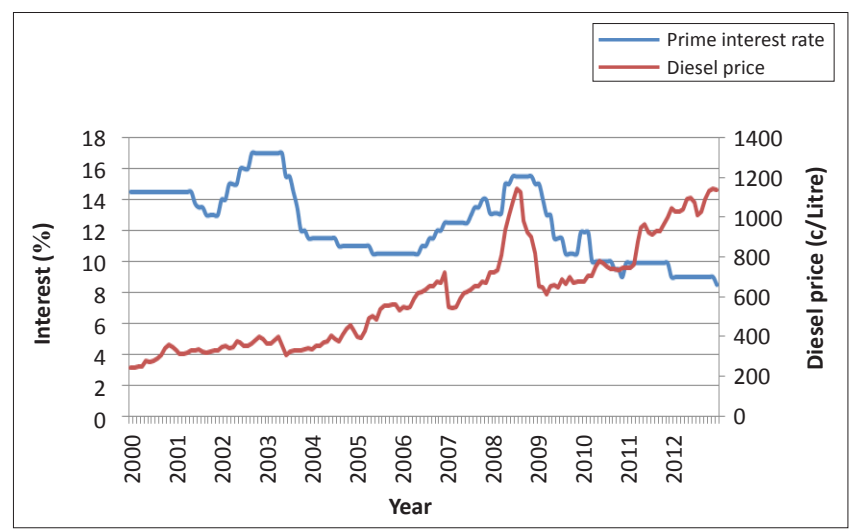

FIGURE 3: Trends in South Africa's fuel price and prime interest rate.

generally considered to be bullish for oil. This bullish view was held because of the aim to stimulate the US economy by quantitative easing, which would increase oil demand, and also because of the increase in dollar-denominated money supply lowering the value of oil (as it is priced in dollars), making oil purchases cheaper for non-dollar economies (Maroo 2012). Obadi (2012) showed a statistically significant negative correlation between the US dollar and the oil price. According to Gilmer (2011), 20\% of the oil price peak in 2011 was attributable to dollar depreciation. 


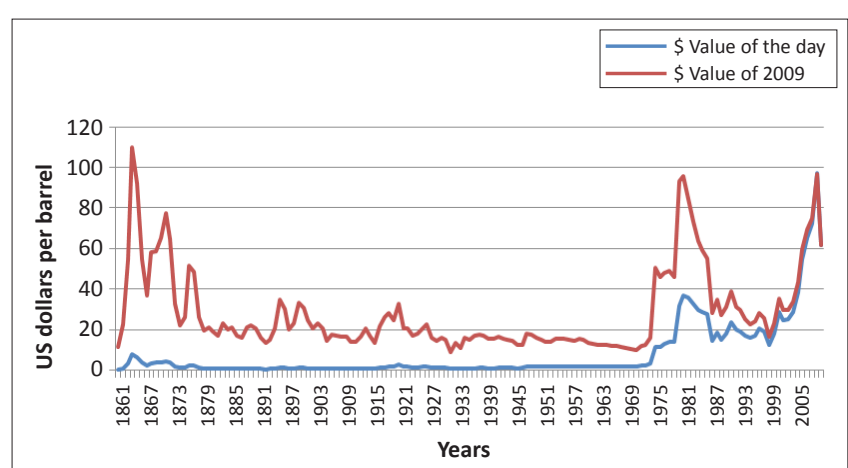

Source: based on data from WTRG Economics, 2012, History of Illinois basin posted crude oil prices, viewed 19 March 2013, from http://www.ioga.com/Special/crudeoil_Hist.htm FIGURE 4: USA crude oil prices.

Further deterioration in the oil price is expected; this is due to the physical production limits imposed by geological constraints despite technological solutions (and therefore increased production) enabled by higher oil prices (Benes et al. 2012). Increased demand from countries like China and India and continued political turmoil in the Middle East, the world's largest oil-supply region, will have a further negative effect on oil prices (Franke 2012).

The bottom-line is that, whilst the causalities between the oil price and other macroeconomic phenomena are complex, the oil price is expected to continue its upward trajectory with concomitant significant impacts on transport costs. This will therefore necessitate a redefinition of production and supplychain structures.

\section{A new logistics paradigm: A reduction in material logistics requirements}

Logistics is driven by trade-offs. On an operational level, it reflects trade-offs between choices within a logistics-cost element (e.g., the use of road or rail transport), or between elements such as transport and the cost of carrying inventory (e.g., paying more for just-in-time deliveries whilst reducing inventories). On a strategic level, trade-offs exist between logistics and other marketing functions, such as product and promotion. On a global development level, society has made the trade-off in favour of additional logistics costs (economic specialisation increases logistics demand) to support scale economics and economic growth.

Klaus (2009) conducted an analysis of the relationship between logistics spending and GDP. He confirmed the role of specialisation; that is, as economies grow, specialisation increases, time and place disparity worsens and logistics spending increases. He did, however, find an indication of maturity in highly developed countries where the logistics role as a facilitator of growth might decline. Klaus observed that global integration is reaching a limit for these economies and he predicted stagnation, or even decline, in the logistics' role, as the need for industrial distribution activities will not grow further. The 'march' of material logistics may come to a halt (Klaus 2009).

The challenges to the logistics discipline is therefore complex, given the fast-accelerating changing landscape of environmental, fuel cost and supply security risks in complex chains, such as the major food chain scandal, which illustrated the complexities in managing visibility in the supply chain (Busicchia 2013; Ruddick 2013). In fact, all 'externalities' (costs that society currently bears and are therefore crosssubsidised and hidden) could be charged to logistics in the future. It is important to bear in mind that these costs already exist and are currently ignored in the specialisation benefits or logistics costs trade-off (Swarts et al. 2012). New and innovative ways of improving logistics (and especially transport) supply side efficiency (the provision of logistics services) and managing logistics demand downwards is essential.

McKinnon (2012) gave one of the most well-researched supply side-solution summaries. He recommended modal shift, better vehicle utilisation, improved fuel efficiency and cutting the carbon content of fuel. McKinnon also added a demand-side solution to lower transport intensity. Demandside solutions are less well researched and will require much more attention in the future, both in South Africa and globally. Some disparate thoughts on the flattening of the international trade curve, the relocalisation of supply (nearshoring and reshoring), with recycling at source and even 3-D printing, have been put forward by some researchers, but have not been researched in detail. Recent exceptions are nearshoring and reshoring, which are receiving increasing attention over the last year.

The Massachusetts Institute of Technology forum for Supply Chain Innovation's reshoring survey concluded that nearly half of the USA's manufacturers are considering reshoring (Simchi-Levi 2012). The MIT survey echoed the results of two more informal research projects by Free (2012) and McMeekin and McMackin (2012). Free (2012), in a supplyside survey, reported that $40 \%$ the USA's manufacturers won previously-offshored manufacturing businesses in the first few months of 2012. McMeekin and McMackin (2012) quoted studies from various consulting groups (such as the Boston Consulting Group and PricewaterhouseCoopers, which confirmed that $50 \%$ of executives from companies with a turnover of more than US $\$ 10$ billion are planning, or actively considering, reshoring. It is estimated that by as early as 2015 , two million to three million jobs and US $\$ 100$ billion of local output, could be created by reshoring.

These trends are too recent to be reflected in official statistics, but initiatives from industry heavyweights confirm the survey findings. Caterpillar, General Electric, Ford, Apple, Coleman and Master Lock have announced that they are shifting some manufacturing operations back to the USA (Plumer 2013; Moneynews 2013). In January 2013, Walmart announced that it would spend an additional US\$50 billion on Americanmade goods over the next ten years (Moneynews 2013). In Europe, Meccano moved a segment of its toy production back to France from China (EDPA 2011). Other examples are: Genevieve Lethu, a French producer of high-quality kitchen accessories; Kapsch, an Austrian producer of radio technology; and Berndes, a German producer of high-quality 
cooking utensils. They all moved parts of their production back from China to their respective home countries (Gärtner 2013).

The key driving forces for these reshoring initiatives are cited to be increasing wages in China, higher international transport costs and quality challenges. Proximity to markets also allows responsiveness to local needs, whilst the utilisation of available local production capacity is favoured in a challenging global economic environment.

These trends are expected to result in a decrease of global trade as a percentage of global GDP in the next few years (Figure 5).

Van den Bergh and Lewer (2007) discussed the conflict between Robertson's claim that trade is an 'engine of growth' and Kravis's qualification that trade is a 'handmaiden of growth'; Robertson's observation was from 1931 and Kravis's from 1970. In the next forty-year wave (where we are now) new research might indicate that trade is not necessarily conducive to growth. In fact, growth itself might be redefined.

\section{Intrinsic questions about the denominator}

The balanced view of sustainable development first proposed by the World Commission on Environment and Development (United Nations 1987) has been generally accepted as a valid construct. This view calls for an equal balance between economic growth, social development and environmental protection. Sustainable Aotearoa New Zealand (a national sustainability research organisation) questioned the balanced version of this 'triple bottom line' model (Sustainable Aotearo New Zealand). The organisation lamented the fact that the version where all attention is given to GDP growth alone is prevalent, and proposed the 'strong' model where GDP growth is seen to be less important than environmental protection and social development. The study rejected the balanced model in favour of the strong environmental model, referred to the 'insidious influence' of the triple bottom line model and expressed dissatisfaction that stakeholders are led astray by it. In fact, GDP growth as such, is questioned.

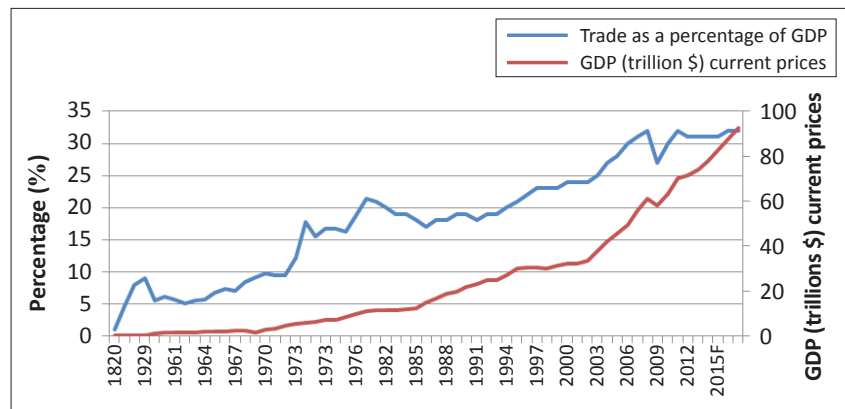

Source: International Monetary Fund, 2013, World Economic Outlook Update: Gradual Upturn in Global Growth During 2013, viewed 08 March 2013, from www.imf.org/external/ pubs/ft/weo/2013/update/01/index.htm and Van den Bergh, H. \& Lewer, J.J., 2007, International Trade and Economic Growth, M.E. Sharpe, Armonk

FIGURE 5: World trade as a percentage of world Gross Domestic Product.
Shutt (1998), called for a new world order where the maximisation of profit would no longer be the basis for allocating resources and referred to the explicit recognition of the limited scope for growth. Fioramonti (2013), in a comprehensive narrative that summarised the rise and possible future fall of GDP, referred to 'a downscaling of production and consumption that increases human wellbeing and enhances ecological conditions and equity on the planet'. Daly and Posner (2011) summarised the 'case against GDP' in terms of the three pillars of sustainability. In growth terms, GDP does not distinguish between speculative gains and real economic value, and does not measure non-market activities that contribute to growth. In social terms, GDP does not measure growth distribution at a household level; it measures quantity and not quality and does not distinguish between 'positive' welfare spending and 'defensive' spending. Social wellbeing indicators such as poverty, literacy and life expectancy are mostly excluded. Sustainability issues are largely ignored.

The Commission of the European Communities (2009) took a more cautious view and accepted the power of GDP to monitor 'short to medium term fluctuations in economic activity' and stated that it is still the best single measure of how a market economy is performing. GDP can however measure longer-term progress and a clear case exists for complementing it with more robust long-term measures. If the world continues to move in this direction, new indicators for the measurement and comparison of logistics costs amongst nations will be needed.

\section{Conclusion}

The USA and South Africa's logistics costs-time series are the only two statistically-based time series available worldwide. They indicate that transportation is becoming a larger portion of total logistics costs, as the key underlying cost driver (oil price) has increased exponentially over the past decade. Expectations are that this volatility will continue as energy supplies become more challenged amidst unprecedented demand. In addition, 'visible' logistics costs will escalate further due to the inclusion of externality charges, which will force a reduction in the logistics environmental footprint. This implies that the paradigm where society, albeit not always consciously, makes the trade-off in favour of high-logistics costs to drive economic growth, needs to be revisited. From a logistics supply-side perspective, optimal modal balance and efficiencies can be engineered, but research is increasingly indicating that the most sustainable long-term approach would be to reduce the demand for material logistics services through reducing demand for material goods. This includes shifting demand to locally-produced goods as well as reshoring the production of necessary material goods. The use of materials that are available locally to manufacture those goods should also be incentivised where possible, for example, using locally grown timber for countertops instead of Italian marble. The mainstream focus on GDP as the key measure of national well-being is therefore questionable, and it is suggested that new measures for the comparison of logistics costs amongst nations will be required. 


\section{Acknowledgements Competing interests}

The authors declare that they have no financial or personal relationship(s) that may have inappropriately influenced them in writing this article.

\section{Author contributions}

J.H.H. (University of Stellenbosch) was responsible for the design and writing of the article; Z.S. (University of Stellenbosch) conducted the modelling; A.d.B. (University of Stellenbosch) was responsible for the project work of the article.

\section{References}

Benes, J., Chauvet, M., Kamenik, O., Kumhof, M., Laxton, D., Mursula, S., et al., 2012, 'The future of oil: Geology versus technology', working paper [WP/12/109], IMF, Washington, viewed 19 August 2013, from http://www.imf.org/external/pubs/ft/ wp/2012/wp12109.pdf

Bogetić, Z. \& Fedderke, J., 2006, 'International Benchmarking of South Africa's Infrastructure Performance', Journal of Development Perspectives 2(1), 7-31.

Brush, S., 2012, 'Lawmakers urge U.S. court to uphold CFTC speculation limits', Bloomberg, viewed 15 May 2012, from www.bloomberg.com/news/2012-04-13/ senators-urge-u-s-court-to-uphold-cftc-speculation-limits-1-.html

Busicchia, B., 2013, 'Horse meat scandal's long tail highlights risks of lengthy supply chains', viewed 19 March 2013, from http://www.theconversation.edu.au/horsemeat-scandals-long-tail-highlights-risks-of-lengthy-supply-chains-12396.

Chan, V., 2013, 'What Currency War?' Chicago Policy Review, 25 April 2013, viewed 08 May 2013, from http://www.chicagopolicyreview.org/2013/04/25/whatcurrency-war/

Commission of the European Communities, 2009, Communication from the commission to the council and the European Parliament: GDP and beyond: Measuring progress in a changing world. Brussels, 20.8.2009, COM 433I.

Daly, L. \& Posner, S., 2011, Beyond GDP: New measures for a new economy, Dēmos, New York, USA.

EDPA, 2011, 'Meccano Toys Moves Back to Northern France', Economic Developmen Press Agency, viewed 06 May 2013, from http://www.edpressagency.blogspot. com/2011/11/meccano-toys-moves-back-to-northern.html

Eghbal, M., 2008, 'Special report: The 1979 vs 2008 oil spike', Euromonitor International, viewed 16 May 2013, from http://www.blog.euromonitor. com/2008/08/special-report-the-1979-vs-2008-oil-spike.html

Engblom, J., Solakivi, T., Töyli, J. \& Ojala, L., 2012, 'Multiple-method analysis of logistics costs', International Journal of Production Economics 137(1), 29-35. http://dx.doi. org/10.1016/j.ijpe.2012.01.007

Fantazzini, D., Höök, M. \& Angelantoni, A., 2011, 'Global oil risks in the early 21st century', Energy Policy 39(12), 7865-7873. http://dx.doi.org/10.1016/j. enpol.2011.09.035

Fedderke, J., Perkins, P. \& Luiz, J., 2006, 'Infrastructural Investment in Long-run Economic Growth: South Africa 1875-2001', World Development 34(6), 10371059. http://dx.doi.org/10.1016/j.worlddev.2005.11.004

Fioramonti, L., 2013, Gross Domestic Problem: Economic Controversies, Zed Books, UK, Kindle Edition. PMCid:PMC3716881

Fourie, J., 2008, 'A note on infrastructure quality in South Africa', Developmen Southern Africa 25(4), 481-494. http://dx.doi.org/10.1080/03768350802318639

Fontevecchia, A., 2012, Bernanke's QE Pickle: Rising Oil Prices And Vicious Feedback Loops, viewed 08 May 2013, from www.forbes.com/sites/ afontevecchia/2012/02/24/bernankes-qe-pickle-rising-oil-prices-and-viciousfeedback-loops/

Franke, P., 2012, Crude oil is going to $\$ 500$ a barrel (Part 1), viewed 24 May 2013 from http://www.beta.fool.com/quantemonics/2012/03/21/crude-oil-going 500-barrel-part-2/3024/

Free, M., 2012, Is the Re-shoring of Manufacturing a Trend or a Trickle?, viewed 08 March 2013, from http://www.forbes.com/sites/mitchfree/2012/06/27/is-there-shoring-of-manufacturing-a-trendor-a-trickle/

Gärtner, M., 2013, 'Erste Firmen blasen zum China-Rückzug', Manager Magazin Online, viewed 08 May 2013, from http://www.manager-magazin.de/politik/ weltwirtschaft/0,2828,807918,00.html

Gilmer, A., 2011, How Much of the Price of Oil is Due to Dollar Weakness?, viewed 07 May 2013, from http://www.oilprice.com/Energy/Oil-Prices/How-Much-Of-ThePrice-Of-Oil-Is-Due-To-Dollar-Weakness.html

Gourdin, K.N., 2001, Global logistics management: A competitive advantage for the new millennium, Blackwell Publishing Limited, Oxford.
Havenga, J., 2010, 'Logistics costs in South Africa - The case for Macroeconomic measurement' South African Journal of Economics 78(4), 460-478. http://dx. doi. org/10.1111/j.1813-6982.2010.01252.x

Hopkins, K., 2008, 'Fuel prices: Iran missile launches send oil to $\$ 147$ a barrel record', The Guardian, viewed 21 May 2012, from www.guardian.co.uk/business/2008/ jul/12/oil.commodities

IEA (International Energy Agency), 2004, Analysis of the impact of high oil prices on the global economy, viewed 05 June 2012, from http://www.allafrica.com/ download/resource/main/main/idatcs/00010270:2043de08f3df04dc11065547c 17b3e71.pdf

International Monetary Fund, 2013, World Economic Outlook Update: Gradual Upturn in Global Growth During 2013, viewed 08 March 2013, from www.imf.org/ external/pubs/ft/weo/2013/update/01/index.htm .

Jegarajah, S., 2013., 'Bernanke May Limit Oil's Decline With QE "Defense"', CNBC viewed 08 May 2013, from http://www.cnbc.com/id/100489005

Klaus, P., 2009, 'Logistics research: A 50 years' march of ideas', Logistics Research 1(1), 53-65. http://dx.doi.org/10.1007/s12159-008-0009-y

Kwon, H. \& Beom, S., 2012, 'Improving the Method for Estimation National Logistics Costs-Koti World Brief', The Korea Transport Institute 4(44), n.p.

Lakshmanan, T.R. \& Anderson, W.P., 2002, Freight Services and Economic Growth: A Synopsis of a White Paper, The US Department of transportation, Federal Highway Administration, Washington.

Manrodt, K. \& Holcomb, M., 2011, '20th annual trends and issues in logistics and transportation study - Operating in the new normal', viewed 04 June 2012, from www.ey.com/Publication/vwLUAssets/20th annual trends and issues in logistics_and_transportation_study/\$FILE/2011_Annual_Logistics_Transportation_ Trends.pdf

Maroo, J., 2012, QE3: The next big driver for oil prices?, viewed 08 May 2013, from www.risk.net/energy-risk/feature/2208245/qe3-the-next-big-driver-for-oil-prices

McKinnon, A.C., 2009, 'The present and future land requirements of logistical activities', Land Use Policy 26S(1), S293-S301. http://dx.doi.org/10.1016/j. landusepol.2009.08.014

McKinnon, A.C., 2012 Green Logistics, global trends and issues, presented at the World Bank Conference: Decoding Sustainable Logistics Trends, Washington: The World Bank, 26 June, 2012.

McMeekin, B. \& McMackin, E., 2012, Reshoring U.S. Manufacturing: A Wave of the Present. Business Climate, viewed 08 March 2013, from http://www. businessclimate.com/blog/2012/09/reshoring-u-s-manufacturing-a-wave-of-thepresent

Moneynews, 2013, Made in America Label Stages Comeback at US Stores, viewed 07 May 2013, from www.moneynews.com/Economy/America-manufacturingadvantage-imports/2013/05/03/id/502731

Obadi, S.M., 2012, To what extent do oil prices depend on the value of US dollar: Theoretical investigation and empirical evidence, viewed 20 September 2013, from http://cdn.intechopen.com/pdfs/32411/InTech-To_what_extent_do_oil prices_depend_on_the_value_of_us_dollar_theoretical_investigation_and_ empirical evidence.pdf

Piecyk, M. \& McKinnon, A.C., 2007, Internalising the External Costs of Road Freight Transport in the UK, Heriot-Watt University, Edinburgh.

Pienaar, W.J. \& Vogt, J.J., 2009, Introduction to business logistics: Business Logistics Management, Oxford University Press, Cape Town.

Plumer, B., 2013, 'Is U.S. manufacturing making a comeback - or is it just hype?', The Washington Post, viewed 06 May 2013, from http://www.washingtonpost.com/ blogs/wonkblog/wp/2013/05/01/is-u-s-manufacturing-set-for-a-comeback-or-isit-all-hype/

Rantasila, K. \& Ojala L., 2012, Measurement of National-Level Logistics Costs and Performance: Discussion Paper 2012-04, International Transport Forum at the OECD, Paris.

Rasamit, T., 2003, 'The aggregate analysis of logistics costs and total factor productivity', Masters thesis, Dept. of Engineering, Massaschusetts Institute of Technology, USA.

Ravn, M.O. \& Mazzenga, E., 2004, 'International business cycles: The quantitative role of transportation costs', Journal of International Money and Finance 23(4) 645-671. http://dx.doi.org/10.1016/j.jimonfin.2004.03.001

Roberts, P.O., 2003, 'Supply chain management: New directions for developing economies', PSD Professionals' Forum, viewed 04 June 2002, from http://www. logmgt.nkmu.edu.tw/news/articles/SCM-New\%20Direction.pdf

Rodrigue, J-P, Comtois, C. \& Slack, B., 2009, The Geography of Transport Systems, Routledge Publishers, New York.

Ruddick, G., 2013, UK supply chains need overhaul to avoid new horse meat scandal survey warns, viewed 19 March 2013, from http://www.telegraph.co.uk/finance/ newsbysector/retailandconsumer/9922860/UK-supply-chains-need-overhaul-toavoid-new-horse-meat-scandal-survey-warns.htm

Schlumberger, C.E., 2009, 'The oil price spike of 2008: The result of speculation or an early indicator of a major and growing future challenge to the airline industry?', Annals of Air and Space Law 34(1), 111-150.

Shutt, H., 1998, The trouble with capitalism: An enquiry into the causes of global economic failure, Zed Books, London.

Simchi-Levi, D., 2012, U.S. Re-Shoring: A Turning Point, Massachusetts Institute of Technology, USA. 
Solakivi, T., Ojala, L., Lorentz, H., Laari, S. \& Töyli, J., 2012, Finland State of Logistics 2012, Ministry of Transport and Communications Finland and The Finnish 2012, Ministry of Transport and Com
Transport Agency. PMCid:PMC3384647

Sustainable Aotearoa New Zealand, 2009, Strong sustainability for New Zealand: Principles and Scenarios, Nakedize Limited, New Zealand.

Swarts, S., King, D., Simpson, Z., Havenga, J. \& Goedhals-Gerber, L., 2012, 'Calculation of freight externality costs for South Africa', Journal of Transport and Supply Chain Management 4(1), n.p.

Transportation Economics \& Management Systems (TEMS), 2008, 'Impact of high oil prices on freight transportation: Modal shift potential in five corridors: Technical report', prepared for: Maritime Administration, U.S. Department Of Transportation, October 2008
United Nations, 1987, Report of the World Commission on Environment and Development: Our Common Future, viewed 08 March 2013, from http://www.undocuments.net/our-common-future.pdf

United Nations, 2002, Commercial Development of Regional Ports as Logistics Centres, United Nations Publications, New York.

Van den Bergh, H. \& Lewer, J.J., 2007, International Trade and Economic Growth, M.E. Sharpe, Armonk.

Wilson, R., 2011, 21st Annual State of Logistics Report: The Great Freight Recession, Council of Supply Chain Management Professionals, Washington.

WTRG Economics, 2012, History of Illinois basin posted crude oil prices, viewed 19 March 2013, from www.ioga.com/Special/crudeoil_Hist.htm 